\title{
MENGENAL PENDIDIKAN KEIMANAN DALAM AL-QURAN
}

\author{
Hoktaviandri \\ Sekolah Tinggi Agama Islam (STAI), YPI Al-Ikhlas Painan \\ Jl. Parak Gadang No.005 Nagari Sago (Depan Terminal Sago) Kecamatan \\ IV Jurai Kabupaten Pesisir Selatan, Padang Sumatera Barat \\ Email:hokta.viandri81@gmail.com
}

Diterima: 10 Maret 2017

Revisi: 20 April 2017

Disetujui: 5 Mei 2017

\begin{abstract}
Man was created by Allah SWT as a peadagogical creature in the sense of having the potential to be educated and educated. In principle the goal of man is created is to worship him. Anything done just wishes Allah SWT. For worship that is done in accordance with his expected then the deed should be based on faith. The potential offaith has existed from the time humans were born. Therefore, faith needs to be continually nurtured through education.
\end{abstract}

Keywords: Peadagogical, educated and educated, and potential of faith

\begin{abstract}
Abstrak
Manusia diciptakan Allah SWT sebagai makhluk peadagogis dalam arti mempunyai potensi dididik dan mendidik. Pada prinsipnya tujuan manusia diciptakan adalah untuk beribadah kepada-Nya. Setiap apa yang dilakukan hanya mengharap ridha Allah SWT. Agar ibadah yang dikerjakan sesuai dengan yang diharapkan-Nya maka perbuatan itu hendaklah didasari oleh keimanan. Potensi beriman sudah ada sejak manusia dilahirkan. Oleh karena itu, iman perlu terus ditumbuhkembangkan melalui pendidikan.
\end{abstract}

Kata kunci: Pedagogi, pendidik dan pendidikan, dan potensi keimanan

\section{A. Pendahuluan}

Muncul dan keberadaan suatu pendidikan di muka bumi ini - secara langsung sudah ada sejak manusia itu sendiri hadir di muka bumi ini. Secara 
historis dan kronologis pendidikan dimulai dari hal yang sangat sederhana, yaitu ketika orang tua mendidik anaknya, atau anak belajar kepada orang tuanya atau kepada orang lain yang lebih dewasa di lingkungannya. Intinya anak belajar agar mampu menghadapi tugas-tugas kehidupan, mencari solusi untuk memecahkan dan mengatasi problem yang dihadapi sehari-hari. ${ }^{1}$ Di dalam al-Quran pendidikan pertama dan mendasar yang harus diberikan kepada anak adalah persoalan keimanan (aqidah). Sesungguhnya kewajiban utama seorang murabbi (pendidik) adalah menjaga fitrah dari penyimpangan dan melindungi aqidah dari kesyirikan. ${ }^{2}$

Pada bagian lain, kemajuan dan kemunduran suatu bangsa antara lain dapat ditentukan dengan kwalitas pendidikannya, sebab pendidikan dapat meningkatkan derajat ilmu pengetahuan dan tingkah laku manusia ke arah yang lebih baik. Jalaluddin Rakhmat menyatakan bahwa pendidikan merupakan upaya mengubah orang dengan pengetahuan tentang sikap dan perilakunya, sesuai kerangka nilai tertentu. ${ }^{3}$

Ilmu pengetahuan dan perilaku yang ada pada manusia akan memberikan kemashlahatan bagi dirinya dan orang lain manakala disertai dengan keimanan kepada Allah Swt dan unsur lainnya yang wajib diimani. Pendidikan yang terlepas dari keimanan akan menghasilkan manusia sebagai anak didik yang tidak berguna bahkan merugikan berbagai pihak. Dalam kontek negara Indoneseia, fenomena krisis multi dimensional disebabkan oleh adanya krisis akhlak. Di berbagai daerah telah terjadi berbagai tindakan kejahatan antara lain: pembunuhan, perampokan, prostitusi, dan korupsi di semua lini yang sampai saat ini masih belum bisa dihapuskan. Menurut Ahmad Tafsir terjadinya kenyataan di negeri ini karena kesalahan dalam pendidikan, yaitu pendidikan nasional di Indonesia tidak mengarahkan manusia kepada

1 Tim Broad Based Education Depdiknas, Kecakapan Hidup Melalui Pendekatan Pendidikan Berbasis Luas, (Surabaya: SIC, 2002), h. 14.

2 Syaikh Khalid Abdurrahman al-Ikk, Pedoman Pendidikan Anak Menurut Al-Qur'an Dan Sunnah, (Solo: al-Qowam, 2009), h. 162.

3 Jaluddin Rakhmat, Islam Alternatif Ceramah-Ceramah Di Kampus, (Bandung: Mizan, 2003), h. 114. 
pendidikan keimanan dan akhlak mulia, tetapi lebih terarah pada penciptaan manausia Indonesia yang utuh, yang tidak jelas wujud dan kriterianya. ${ }^{4}$

Islam merupakan suatu agama yang universal, semua hal ini tampak di jendela-jendela kehidupan masa lalu, yang membuktikan bahwa berbagai aspek-aspek kehidupan itu terjadi, baik di segi sosial, budaya, politik. Akan tetapi aspek yang paling menonjol pada saat islam akan bergejolak adalah mengenai penyembahan, baik itu yang benar (tauhid), maupun yang salah (berhala). Seiring berubahan perubahan itu, dengan datang utusan Allah di permukaan bumi ini tepat Baginda Rasulullah saw, yang berjuang untuk menyebarkan ajaran-ajaran tentang Islam. Yang terpenting pada saat itu adalah pendidikan tentang ketauhidan atau tentang ketuhanan, dengan memberikan dogma-dogma pembuktian tentang keberadaan Allah swt, baik secara aqli maupun naqli yang esensinya adalah untuk mecapai iman yang benar-benar sesuai dengan tuntunan rasulullah saw.

Membincangkenalkan tentang keimanan itu sangatlah luas cakupannya, akan tetapi pada artikel ini akan dideskripsikan proses keimanan itu akan tercapai apabila pembuktian-pembuktian tentang ketauhidan yang berada di dalam suatu kitab (al-Quran alkarim). Yang diberi metode-metode kajian untuk mempelajari kitab tersebut, dan salah satu metode pembahan itu adalah ilmu tafsir, dengann demikian seiring ingin memahami keimanan yang terdpat di dalam kitab suci Alquran, sudah semestinya juga senada dengan ilmu tafsir. Agar permasalahan-permasalahn keimanan mudah di pahami dengan suatu disiplin ilmu. Berkenaan dengan hal tersebut, pendidikan keimanan cakupannya sangat luas dan sangat banyak ayat-ayat al-Qur $\square$ an dan Hadits yang mengisyaratkan tentang pendidikan keimanan, antara lain di dalam surat al-Baqarah ayat 133 Allah SWT berfirman.

4 Ahmad Tafsir, "Pendidikan Keimanan Sebagai Core Sistem Pendidikan (Upaya Strategis Menyelamatkan Bangsa," in Ta'dib Jurnal Pendidikan Islam, No. 2, vol. Vol. 1, 2001, h. 131. 


\section{B. Pendidikan Keimanan dan Konsepnya}

\section{Terminologi Pendidikan Keimanan}

Pendidikan Keimanan terdiri dari dua kata, yaitu kata pendidikan dan kata keimanan. Kata pendidikan sudah akrab dalam kehidupan seharihari masyarakat, meski dalam pemahaman hakekat dan makna masih beragam. Keberagaman pemaknaan pendidikan tersebut tidak hanya terjadi di kalangan masyarakat umum, tetapi juga pada ahli pendidikan. Masingmasing memiliki definisi yang berbeda antara satu dengan yang lainnya. Hal tersebut dapat dilihat antara lain, Darmaningtyas mendifinisikan pendidikan sebagai usaha sadar dan sistematis untuk mencapai taraf hidup atau kemajuan yang lebih baik. ${ }^{5}$

Titik fokus dari difinisi ini adalah "usaha sadar dan sistematis." Dengan demikian, tidak semua usaha yang memberikan bekal pengetahuan kepada anak didik dapat disebut pendidikan jika tidak memenuhi kriteria yang dilakukan secara sadar dan sistematis. Ngalim Purwanto mendifinisikan pendidikan sebagai usaha orang dewasa dalam pergaulannya dengan anakanak untuk memimpin perkembangan jasmani dan ruhani mereka ke arah kedewasaan. ${ }^{6}$ Sementara itu, Suparlan membagi definisi pendidikan ke dalam dua bentuk, yakni dalam arti luas dan dalam arti sempit.

Dalam arti luas pendidikan merupakan sistem perubahan menuju pendewasaan, pencerdasan dan pematangan diri. Sedangkan dalam arti sempit pendidikan adalah seluruh kegiatan belajar yang direncanakan, dengan materi terorganisasi, dilaksanakan secara terjadwal dalam pengawasan dan diberikan evaluasi berdasarkan tujuan yang telah ditentukan. Pendidikan dalam arti sempit bukan berarti memotong isi dan materi pendidikan, melainkan pengorganisasian pendidikan dalam bentuk sederhana tanpa mengurangi kualitas dan hakekat pendidikan. ${ }^{7}$ Dari

\footnotetext{
5 Darmaningtyas, Pendidikan Yang Memiskinkan, (Yogyakarta: Galang Press, 2004), h.1.

6 Ngalim Purwanto, Ilmu Pendidikan, Teoritis Dan Praktis, (Bandung: Remaja Rosda Karya, 1995), h. 11.

7 Suparlan Suhartono, Filsafat Pendidikan, (Yogyakarta: ar-Ruzz Media, 2009), h. 80.
} 
beberapa definisi di atas terlihat dimensi yang berbeda antara pengertian yang disampaikan para ahli. Namun dari keragaman tersebut terdapat kesamaan yang dianggap sebagai titik temu yaitu adanya aspek proses menuju kedewasaan dan memanusiakan manusia.

Pengertian keimanan antara lain dalam Kamus Besar Bahasa Indonesia, keimanan; asal katanya Iman berawalan ke dan akhiran an, Iman artinya kepercayaan (yang berkenaan dengan agama); keimanan: 1). Keyakinan dan kepercayaan kepada Allah SWT, Nabi, Kitab dan sebagainya; tidak akan bertentangan dengan ilmu. 2). Ketetapan hati, keteguhan bathin, keseimbangan bathin. Sedangkan beriman artinya mempunyai iman (ketetapan hati), mempunyai keyakinan dan kepercayaan kepada Tuhan yang Maha Esa. Setiap muslim wajib memperkuat keyakinannya kepada Allah SWT. ${ }^{8}$

Berdasarkan Tafsiran Mufradat kata amana menurut bahasa berarti altashdiq (Pembenaran), baik dilakukan dengan hati maupun dengan lidah. ${ }^{9}$ Dalam Ensiklopedi Islam, Iman didefenisikan sebagai keyakinan terhadap Allah SWT, Malaikat-Nya, Kitab-kitab-Nya, Rasul-Nya, hari kiamat, serta beriman kepada qadha dan kadar. ${ }^{10}$ Dalam Hadits Nabi Saw, iman diartikan:

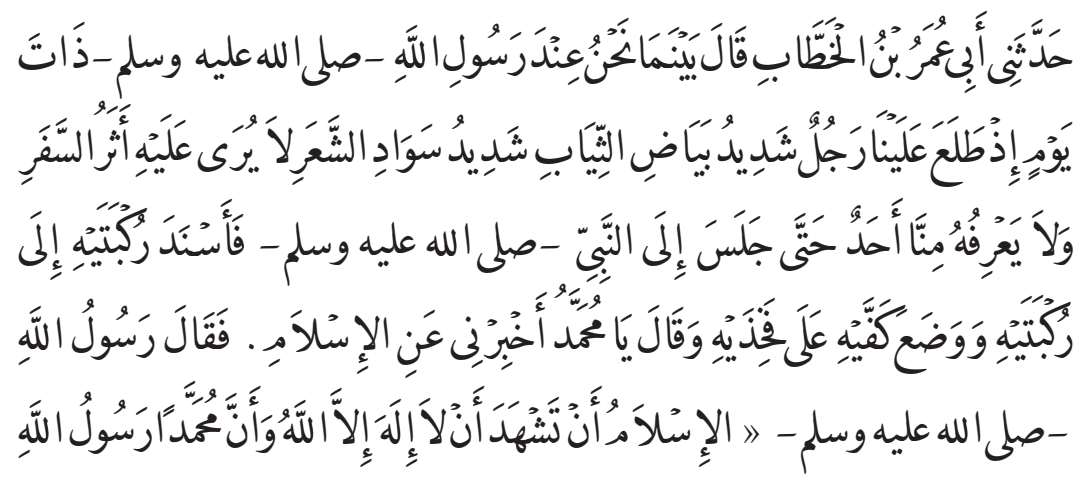

8 Tim Penulis, "Kamus Besar Bahasa Indonesia," (Jakarta: Balai Pustaka, 2002), 425.

9 Hasan Zaini, TafsirTematik Ayat-Ayat Kalam, (Jakarta: Radar Jaya Offset, 1997), h. 83.

${ }^{10}$ Hustan Smith and Cyril Glasse, Ensiklopedi Islam (Ringkas), trans. Ghufran, A. Mas'adi, 1st ed., vol. cet. 2 (Jakarta: Raja Grafindo Persada, 1999), h. 169. 


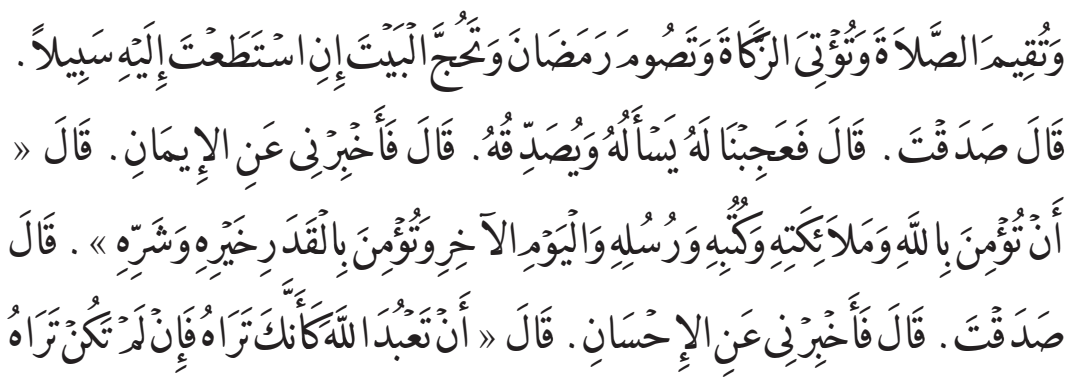

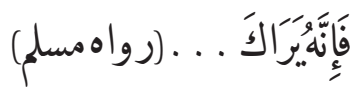

Artinya: Hadits ini dari shabat Umar bin Khatab, pada suatu hari, Rasulullah Saw. muncul di antara kaum muslimin. Lalu datang seorang laki-laki dan bertanya: Wahai Rasulullah, apakah Iman itu? Rasulullah saw. menjawab: Engkau beriman kepada Allah, malaikat-malaikat-Nya, kitab-kitab-Nya, pertemuan dengan-Nya, rasul-rasul-Nya dan kepada hariberbangkit. Orang itu bertanya lagi: Wahai Rasulullah, apakah Islam itu? Rasulullah saw. menjawab: Islam adalah engkau beribadah kepada Allah dan tidak menyekutukan-Nya dengan apa pun, mendirikan salat fardu, menunaikan zakat wajib dan berpuasa di bulan Ramadan. Orang itu kembali bertanya: Wahai Rasulullah, apakah Ihsan itu? Rasulullah saw. menjawab: Engkau beribadah kepada Allah seolah-olah engkau melihat-Nya. Dan jika engkau tidak melihat-Nya, maka sesungguhnya Dia selalu melihatmu. (HR. Muslim). ${ }^{11}$

Dalam Ajaran Islam memiliki dimensi iman, Islam dan amal. Ketiganya berkaitan erat satu dengan lainnya. Aspek Islam dan amal dipandang sebagai bagian berupa ritual dan hukum-hukum. Sementara urusan keyakinan kepada Allah Swt merupakan suatu yang tersusun di dalam pemikiran. Oleh sebab itu untuk mengetahui adanya Allah, seseorang harus yakin terlebih dahulu, keyakinan ini akan mengantarkan menuju pengetahuan tentang Tuhan ${ }^{12}$ Keimanan Muradif-nya adalah Aqidah, dalam bahasa Arab aqidah berasal dari kata $a l-' a q d u$ yang berarti ikatan, at-tautsiiqu yang

${ }^{11}$ Al-Imam Muslim, Shahih Muslim, trans. Makmur Daud, Jilid 1 (Malaysia: Klang Book Centre, 1995), h. 2-3.

${ }^{12}$ Smith and Glasse, Ensiklopedi Islam (Ringkas), cet. 2: h. 169. 
berarti kepercayaan atau keyakinan yang kuat, al-ihkaamu yang artinya mengokohkan (menetapkan), dan ar-rabthubi quw-wah yang berarti mengikat dengan kuat. Sedangkan menurut istilah (terminologi) 'aqidah adalah Iman yang teguh dan pasti, yang tidak ada keraguan sedikit pun bagi orang yang meyakininya.

\section{Prinsip dan Standar Baku: Dasar-dasar Pendidikan Keimanan}

Dasar pendidikan keimanan adalah al-Quran dan al-Sunnah. Artinya apa saja yang disampaikan Allah SWT dalam al-Quran dan oleh rasul-Nya dalam sunnahnya wajib diimani dan diamalkan.

\section{a) Al-Quran}

Al-Quran dijadikan sumber pendidikan yang pertama dan utama karena ia memiliki nilai-nilai absolute yang diturunkan dari Tuhan. Allah Swt yang menciptakan manusia dan Dia pula yang mendidik manusia.

Materi atau isi pendidikan itu termaktub dalam wahyu-Nya. Tidak satu pun persoalan, termasuk persoalan pendidikan yang luput dari petunjuk al-Quran. Al-Quran bukan rekayasa manusia, ia semata-mata firman Allah SWT yang diturunkan kepada Nabi Muhammad SAW. Ajarannya mencakup keseluruhan ilmu pengetahuan. Ia merupakan sumber yang mulia yang esensinya tidak dimengerti oleh semua orang kecuali bagi mereka yang berjiwa suci dan berakal cerdas. Nilai esensi dalam al-Quran selamanya abadi dan selalu relevan dengan setiap waktu dan zaman, tanpa ada perubahan sama sekali.

Perubahan dimungkinkan hanya menyangkut masalah interpretasi mengenai nilai-nilai instrumental dan menyangkut masalah teknik operasional. Pendidikan Islam yang ideal harus sepenuhnya mengacu pada nilai dasar al-Quran, tanpa sedikitpun menguranginya. ${ }^{13} \mathrm{Al}$-Quran adalah petunjuk dari Allah SWT yang apabila dipelajari akan membantu kita

${ }^{13}$ Abdul Mujib and Yusuf Mudzakir, Ilmu-Ilmu Pendidikan Islam, (Jakarta: Kencana Prenada Media, 2006), h. 32-33. 
menemukan nilai-nilai yang dapat dijadikan pedoman bagi penyelesaian berbagai persoalan kehidupan.

Apabila dihayati dan diamalkan akan menjadi buah fikiran, rasa dan karsa kita mengarah kepada realitas keimanan yang dibutuhkan bagi stabilitas dan ketentraman hidup pribadi dan masyarakat. ${ }^{14}$ Pada dasarnya ayat-ayat al-Quran membentuk seluruh sistem pendidikan.

Dalam pandangan Abdurrahman Shalih Abdullah, banyak orang yang tidak mengerti tentang aspek pendidikan yang terkandung dalam al-Quran. Menurutnya ini dimungkinkan karena mereka bingung dalam membuat koneksi antara al-Quran dengan pendidikan serta tidak menemukan dalam al-Quran istilah umum yang dipergunakan dalam dunia pendidikan. ${ }^{15}$ Pendidikan keimanan terhadap anak dijelaskan dalam beberapa ayat dalam al-Quran diantaranya surat al-Baqarah ayat 133, tentang wasiat nabi Ya'kub kepada anaknya untuk selalu menyembah Allah sampai akhir hayatnya, surat lain yang menyebutkan pendidikan keimanan adalah surat Luqman ayat 13 yang berbunyi:

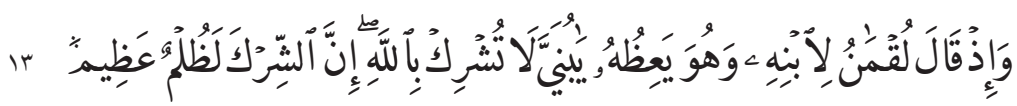

Artinya:"Dan (Ingatlah) ketika Luqman berkata kepada anakny di waktu ia member pelajaran kepadanya: "Hai anakku,janganlah kamu mempersatukan Allah, sesungguhnya mempersatukan (Allah) adalah benar-benar kezaliman yang besar." (QS. Luqman/31:13).

Berdasrkan ayat ini dapat dipahami bahwa di antara kewajiban orang tua kepada anaknya adalah memberi nasihat dan pelajaran, sehingga anakanaknya itu dapat menempuh jalan yang benar dan menjauhkan mereka dari kesesatan. Jika diperhatikan susunan kalimat ayat ini, maka dapat diambil pemahaman bahwa Luqman melarang keras anaknya berbuat syirik.

${ }^{14}$ M. Quraish Shihab, Wawasan Al-Qur'an, (Bandung: PT. Mizan Pustaka, 2004), h. 13.

15 Abdurrahman Shalih Abdullah, Landasan Dan Tujuan Pendidikan Menurut Al-Qur'an Dan Implementasinya, (Bandung: Diponegoro, 1992), h. 43. 
Larangan ini adalah sesuatu yang memang patut disampaikan Luqman kepada putranya karena syirik adalah suatu perbuatan dosa yang paling besar. Seakan-akan dalam ayat ini diterangkan bahwa Luqman telah melakukan tugas yang sangat penting kepada anaknya, yaitu telah menyampaikan agama yang benar dan budi pekerti yang luhur. Cara Luqman menyampaikan pesan itu wajib dicontoh oleh setiap orang tua yang mengaku dirinya muslim. ${ }^{16}$

\section{b) As-Sunnah}

Al-Quran sebagai sumber segala sumber hukum Islam hanyalah memuat prinsip-prinsip dasar ajaran Islam. Adapun sebagian ayatnya yang menguraikan prinsip-prinsip dasar itu masih perlu penjelasan. Penjelasan al-Qur'an dapat dijumpai dalam sunnah Rasul (al-Hadits).

Sunnah rasul itu merupakan cermin dari segala tingkah laku Rasulullah Saw yang harus di teladani. Inilah salah satu alat pendidikan yang paling efektif dalam pembentukan pribadi. Karena keglobalan al-Quran dan tidak dapat diurai kecuali melalui sunnah rasul, maka sumber kedua pendidikan keimanan setelah al-Quran ialah al-Sunnah. ${ }^{17}$

Kedudukan akal dalam pendidikan aqidah bukanlah menjadi sumber, tetapi hanya berfungsi sebagai alat untuk memahami nash-nash yang terdapat dalam kedua sumber tersebut dan mencoba kalau diperlukan membuktikan secara ilmiah kebenaran yang disampaikan oleh al-Quran dan sunnah. Itupun harus didasari oleh suatu kesadaran bahwa kemampuan akal sangat terbatas, sesuai dengan terbatasnya semua makhluk Allah. Akal tidak akan mampu menjangkau masail ghaibiyah (masalah ghaib), bahkan akal tidak akan mampu menjangkau sesuatu yang tidak terikat dengan

${ }^{16}$ Departemen Agama RI, Al-Qur'an Dan Tafsirnya, Jilid VII (Yogyakarta: Dana Bhakti Wakaf, 1995), 636-37.

${ }^{17}$ Abidin Ibn Rusn, Pemikiran Al-Ghozali Tentang Pendidikan, (Yogyakarta: Pustaka Pelajar, 1998), h. 131. 
ruang dan waktu. Oleh karena itu, akal tidak boleh dipaksa memahami hal-hal ghaib tersebut. ${ }^{18}$

\section{Materi Pendidikan Keimanan}

Pada dasarnya manusia mempunyai fitrah. Konsep fitrah menunjukkan bahwa manusia membawa sifat dasar kebajikan dengan potensi iman (kepercayaan) terhadap ke-Esaan Tuhan (tauhid). Sifat dasar atau fitrah yang terdiri dari potensi tauhid itu menjadi landasan semua kebajikan dalam perilaku manusia, dengan kata lain, manusia diciptakan Tuhan dengan sifat dasar baik berlandaskan tauhid. ${ }^{19}$ Agar dalam melaksanakan hidup selalu berada pada jalan yang diridhai Allah diperlukan pedoman dan pegangan yang kokoh dan kuat. Pedoman tersebut harus dilandasi dengan keimanan dan keyakinan yang mendalam, serta terpatri kuat dalam hati sehingga tidak mudah goyah oleh keadaan bagaimanapun.

Dalam melaksanakan ibadah kepada Allah harus di landasi dengan aqidah yang benar dan tertancap kuat dalam hati serta direalisasikan dengan amal ibadah, amal seseorang tidak akan diterima tanpa didasari dengan aqidah yang benar. Seseorang tidaklah dinamai berakhlak mulia apabila tidak memiliki aqidah yang benar, oleh karena itu diperlukan materi-materi pendidikan aqidah. Dalam materi pendidikan aqidah yang pertama diajarkan adalah bagaimana pendidikan menanamkan dalam diri anak hal-hal yang berhubungan dengan kehidupan manusia di dunia ini sebagai jembatan menuju ke alam akhirat.

Dalam hal ini pendidikan aqidah yang diperkenalkan kepada anak adalah rukun iman yang enam, yaitu:

(a) Beriman kepada Allah, dengan mempercayai sepenuh hati akan eksistensi Tuhan dan ke-Esaan-Nya serta sifat-sifat-Nya yang serba sempurna, mengikuti petunjuk Tuhan dan Rasul-Nya yang tersebut

${ }^{18}$ Ilyas Yunahar, Kuliah Aqidah Islam, (Yogyakarta: Lembaga Pengkajian dan Pengamalan Islam-LIPPI, 1992), h. 6.

${ }^{19}$ Munzir Hitami, Mengonsep Kembali Pendidikan Islam, (Riau: Infinite Press, 2004), h. 11. 
di dalam al-Quran dan hadist-hadist Nabi, menjalankan ibadah sesuai dengan tuntunan al-Quran dan sunnah. ${ }^{20}$

(b) Beriman kepada malaikat Allah, dengan mempercayai bahwa Allah menciptakan malaikat-Nya dari nur (Cahaya). Mereka disucikan dari kesyahwatan-kesyahwatan hayawaniah, terhindar sama sekali dari keinginan hawa nafsu, terjauh dari perbuatan dosa dan salah. Tabiat malaikat itu ialah secara sempurna berbakti kepada Allah, melaksanakan semua perintah-Nya, tunduk dan patuh terhadap semua kekuasaan dan keagungan-Nya. ${ }^{21}$

(c) Beriman kepada kitab-kitab Allah, dengan mempercayai bahwa Allah telah menurunkan beberapa kitab-Nya kepada para rasul untuk menjadi pedoman dan pegangan hidup agar mencapai kebahagiaan hidup di dunia dan di akhirat. Kitab-kitab suci yang diturunkan oleh Allah tidak semuanya disebut dalam al-Quran dan hadits nabi yang shahih. Kitab Allah yang secara konkrit disebut namanya dalam alQuran ada 4 (empat), yaitu: Taurat, Zabur, Injil, dan al-Qur $\square$ an. Semua kitab Allah, baik yang empat kitab tersebut maupun yang lainnya, adalah membawa prinsip yang sama yaitu mengajak manusia ke jalan yang benar dan memberi petunjuk kepadanya untuk mencapai kebahagiaan hidup di dunia dan di akhirat. ${ }^{22}$

Kitab suci al-Qur $\square$ an memiliki keistimewaan-keistimewaan sehingga berbeda dengan kitab-kitab lain yang diturunkan sebelumnya, di antaranya:

(1) Al-Quran memuat ringkasan-ringkasan dari ajaran ketuhanan yang pernah dimuat oleh kitab-kitab suci sebelumnya seperti Taurat, Zabur, Injil dan lain-lainnya. Al-Quranjuga mengokohkan perihal kebenaran yang pernah didakwahkan oleh kitab-kitab suci sebelumnya berhubungan dengan peribadatan kepada Allah yang Maha Esa, beriman kepada para rasul, membenarkan

\footnotetext{
${ }^{20}$ Masfuk Zuhdi, Studi Islam, Jilid I (Jakarta: Rajawali, 1988), h. 11.

${ }^{21}$ Sayid Sabiq, Aqidah Islam, (Bandung: Diponegoro, 1993), h. 174.

${ }^{22}$ Zuhdi, Studi Islam, h. 43.
} 
adanya balasan pada hari akhirat, keharusan menegakkan hak dan keadilan berprilku dengan akhlak yang luhur serta budi pekerti yang mulia.

(2) Ajaran-ajaran yang termuat dalam Al-Quran adalah kalimat Allah yang terakhir untuk memberikan petunjuk dan tuntunan yang benar kepada umat manusia dan inilah yang dikehendaki oleh Allah supaya tetap terjaga sepanjang masa, kekal untuk selama-lamanya.

(3) Kitab suci al-Quran dikehendaki oleh Allah akan kekekalannya, tidak mungkin pada suatu saat akan terjadi bahwa ilmu pengetahuan akan mencapai titik hakikat yang bertentangan dengan hakikat yang tercantum dalam al-Quran.

(4) Allah SWT berkehendak supaya kalimat-Nya disebarluaskan dan disampaikan kepada semua akal pikiran dan pendengaran.. Kehendak semacam ini tidak mungkin tercap.ai kecuali kalimat itu sendiri benar-benar mudah diingat, dihafalkan serta difahami. Oleh karena itu, al-Quran sengaja diturunkan dengan gaya bahasa yang istimewa, mudah, tidak sukar bagi siapapun untuk memahaminya, asalkan disertai dengan keikhlasan hati dan kemauan baik. ${ }^{23}$

(d) Beriman Kepada Rasul Allah, dengan mempercayai bahwa Allah telah mengirimkan utusan-utusan-Nya yang membawa wahyu Ilahi untuk disampaikan kepada umat manusia sebagai petunjuk atau pedoman hidup. Kepercayaan kapada rasul-rasul adalah tidak membedakan antara satu dengan yang lainnya.

(e) Beriman kepada hari akhirat, dengan mempercayai bahwa semua kehidupan dunia akan berakhir. Masa itu disebut dengan hari kiamat yang didahului musnahnya alam semesta ini. Semua makhluk hidup akan mati. Setelah itu manusia akan dibangkitkan kembali untuk mempertanggungjawabkan semua perbuatan yang ia lakukan selama hidup di dunia. Akhirnya bagi yang banyak amal kebajikan akan

${ }^{23}$ Sabiq, Aqidah Islam, h. 263-267.

TARBAWIYAH, Jurnal Ilmiah Pendidikan :: Vol. 01 No.1, Juni 2017 p-ISSN: 2579-3241; e-ISSN: 2579-325X 
masuk syurga dan sebaliknya bagi yang banyak dosa akan masuk neraka. ${ }^{24}$

(f) Beriman kepada Qada dan Kadar

Mempercayai bahwa Allah SWT menjadikan makhluk dengan hikmah, kodrat dan iradah-Nya. Manusia diciptakan oleh Allah SWT dengan ketentuan baik dan buruk menurut pandangan manusia. Manusia diwajibkan berusaha semaksimal mungkin dan bertawakkal kepada Allah SWT. Salah satu hikmah beriman kepada qada dan kadar adalah, setelah berusaha maksimal, jika usaha itu berhasil maka keberhasilan itu berkat karunia Allah, sebaliknya jika tidak berhasil semua itu sudah merupakan takdir Allah Swt.

\section{Metode Pendidikan Keimanan}

Agar materi yang disampaikan dapat diterima dengan baik oleh peserta didik secara efektif dan efisien maka diperlukan metode yang tepat dan sesuai dengan materi tersebut. Metode adalah jalan dalam bentuk ide-ide yang mengacu pada cara yang mengantarkan seseorang pada tujuan yang ditentukan. ${ }^{25}$ Dalam kaitannya dengan pendidikan keimanan terhadap anak penulis kemukakan beberapa metode, sebagai berikut:

\section{a. Metode Keteladanan}

Menurut Nashih Ulwan, keteladanan yang baik merupakan metode yang paling berpengaruh dan paling berhasil dalam mempersiapkan serta membentuk aspek moral, spiritual dan etos sosial anak. ${ }^{26}$ Yang ditegaskan di sini adalah keteladanan kedua orang tua terhadap anak-anaknya dalam hal keimanan dan berpegang teguh kepada aqidah Islam serta menjalankan ibadah kepada Allah SWT.

\footnotetext{
${ }^{24}$ Ibid., h. 429-430.

25 Abudin Nata, Filsafat Pendidikan Islam I, (Jakarta: Logos Wacana Ilmu, 1997), h. 83.

${ }^{26}$ Nashih Ulwan, Pedoman Pendidikan Anak Dalam Islam, Jilid II, n.d., h. 142.
} 
Anak akan selalu meniru apa yang dikerjakan oleh kedua orang tuanya. Kecil kemungkinan anak yang hidup bersama orang tua yang tidak mempunyai aqidah yang benar dapat tumbuh menjadi orang yang memiliki keimanan yang kokoh. Jadi keteladanan orang tua sangat mendominasi kehidupan dan jiwa anak. Sebagai umat Islam contoh suri teladan yang baik itu adalah nabi Muhammad SAW. Hal tersebut diabdikan dalam QS. alAhzab ayat 21, yang artinya: Sesungguhnya Telah ada pada (diri) Rasulullah itu suriteladan yang baik bagimu (yaitu) bagiorang yang mengharap (rahmat) Allah dan (kedatangan) hari kiamat dan dia banyak menyebut Allah.

\section{b. Pembiasaan}

Islam menggunakan kebiasaan sebagai salah satu teknik pendidikan. Semua sifat baik menjadi kebiasaan dan dilaksanakan tanpa merasa berat dan tanpa kesulitan. ${ }^{27}$ Anak sejak lahir sudah membawa fitrah keimanan. Sementara itu, untuk mengembangkan fitrah tersebut diperlukan pembiasaan sebagaimana diungkapkan al-Gazali, bahwa anak anak adalah amanah bagi kedua orang tuanya dan hatinya yang suci adalah permata yang sangat mahal harganya apabila ia diajarkan dan dibiasakan pada kebaikan, maka ia akan tumbuh pada kebiasaan itu dan akan mendapatkan kebahagiaan di dunia dan di akhirat. Tetapi apabila dibiasakan untuk berbuat kejahatan dan dibiarkan seperti hewan maka ia akan sengsara dan binasa. ${ }^{28}$ Seorang anak akan mudah meniru. Mereka akan bertingkah laku sesuai dengan apa yang mereka lihat.

Anak akan meniru apa yang dilakukan oleh pujaannya dan akan patuh terhadap apa yang diperintahkan oleh pujaannya. Oleh sebab itu, orang tua harus memberikan teladan kepada anaknya secara konkret bukan hanya sekedar perintah. Orang tua harus berprilaku baik sesuai standar moralitas yang terpuji sebelum mengingatkan anaknya menjadi baik.

${ }^{27}$ Muhammad Qutb, Sistem Pendidikan Islam, trans. Salman Harun (Bandung: al-Maarif, 1993), h. 363.

${ }^{28}$ Nashih Ulwan, Pedoman Pendidikan Anak Dalam Islam, Jilid I, n.d., h. 171. 


\section{c. Nasehat}

Di dalam jiwa terdapat pembawaan untuk terpengaruh oleh kata kata yang didengar. Nasehat akan membawa pengaruh ke dalam jiwa seseorang dan menjadi sesuatu yang besar dalam pendidikan rohani. ${ }^{29}$ Nasehat merupakan metode yang efektif dalam usaha pembentukan keimanan (aqidah), mempersiapkan moral, spiritual, emosional dan sosial anak.

Nasehat dan pituah memiliki pengaruh yang cukup besar dalam membuka mata anak didik akan hakekat sesuatu, mendorongnya menuju harkat dan martabat yang luhur dn menghiasinya dengan akhlak yang mulia serta membekalinya dengan prinsip-prinsip Islam. ${ }^{30}$ Metode nasehat merupakan salah satu metode yang dapat digunakan oleh pendidik dalam menanamkan keimanan kepada peserta didik seperti yang telah dijelaskan al-Qur $\square$ an surat Lukman ayat 13: Dan ingatlah ketika Lukman berkata kepada anaknya, di waktu ia memberi pelajaran kepadanya: "Hai anak-ku, janganlah kamu mempersekutukan Allah. Sesungguhnya mempersekutukan (Allah) adalah benar-benar kezaliman yang besar”. (QS. Lukman, 13).

Dari ayat ini dapat dipahami bahwa di antara kewajiban orang tua kepada anaknya adalah memberi nasehat dan pelajaran sehingga anak tersebut dapat menempuh jalan yang benar dan menjauhkan mereka dari kesesatan.

\section{Tujuan Pendidikan Keimanan}

Pendapat Sayyid Sabiq, tujuan utama pendidikan keimanan adalah memberikan didikan yang baik dalam menempuh jalan kehidupan, mensucikan jiwa lalu mengarahkannya ke jurusan yang tertentu untuk mencapai puncak dari sifat-sifat tinggi dan luhur, dan lebih utama lagi supaya diusahakan agar sampai pada ma'rifat tertingg. ${ }^{31}$ Untuk lebih jelasnya penulis sedikit akan merumuskan tujuan pendidikan.

\footnotetext{
${ }^{29}$ Qutb, Sistem Pendidikan Islam, h. 334.

${ }^{30}$ Ulwan, Pedoman Pendidikan Anak Dalam Islam, Jilid II, h. 209.

${ }^{31}$ Sabiq, Aqidah Islam, h. 19.
} 
Tujuan pendidikan merupakan masalah inti dalam pendidikan, saripati dari seluruh renungan peadagogik. Dengan demikian tujuan pendidikan merupakan faktor yang sangat menentukan jalannya pendidikan sehingga perlu dirumuskan sebaik-baiknya. ${ }^{32}$

Pendidikan nasional berfungsi mengembangkan kemampuan dan membentuk watak serta peradaban bangsa yang bermartabat dalam rangka mencerdaskan kehidupan bangsa, bertujuan untuk berkembangnya potensi peserta didik agar menjadi manusia yang beriman dan bertakwa kepada Tuhan yang Maha Esa, berakhlak mulia, sehat, berilmu, cakap, kreatif, mandiri, dan menjadi warga yang demokratis serta bertanggung jawab. ${ }^{33}$ Sedangkan menurut Ibnu Taimiyah tujuan pendidikan Islam tertumpu pada empat aspek yaitu: pertama tercapainya pendidikan Tauhid dengan cara mempelajari ayat Allah. Kedua mengetahui ilmu Allah Swt melalui pemahaman terhadap kebenaran makhluk-Nya. Ketiga mengetahui kekuatan Allah melalui pemahaman jenis-jenis, kuantitas, dan kreatifitas makhluk-Nya. Keempat mengetahui apa yang diperbuat Allah (sunnah Allah) tentang realitas (alam) dan jenis-jenis perilakunya.

Pendapat al-Ghazali, tujuan umum pendidikan Islam tercermin dalam dua segi yaitu: Pertama insan purna yang bertujuan mendekatkan diri kepada Allah SWT. Kedua insan purna yang bertujuan mendapatkan kebahagiaan hidup di dunia dan di akhirat. ${ }^{34}$

Menurut Achmadi tujuan tertinggi pendidikan Islam adalah menjadikan hamba Allah yang bertaqwa karena manusia diciptakan di dunia semata-mata hanya untuk beribadah kepada Allah, mengantarkan peserta didik menjadi khalifatullah fil ardh yang mampu memakmurkannya (membudayakan alam sekitar) dan memperoleh kesejahteraan, kebahagiaan

\footnotetext{
${ }^{32}$ Achmadi, Ideology Pendidikan Isalm, (Yogyakarta: Pustaka Pelajar, 2010), h. 90.

${ }^{33}$ Undang-undang Republik Indonesia, “Tentang Sisitem Pendidikan Nasional," Pub. L. No. 2, Pasal 3 Bab II (2003), h. 3.

${ }^{34}$ Mujib and Mudzakir, Ilmu-Ilmu Pendidikan Islam, h. 78-79.
} 
dunia dan akhirat. Dengan demikian antara tujuan pendidikan Islam dan pendidikan keimanan saling terkait satu sama lain.

Dalam perkembangan dunia pendidikan peserta didik harus dibekali pendidikan keimanan terlebih dahulu supaya memiliki pendirian dan pegangan yang kokoh dalam kehidupannya. Seseorang yang memiliki keimanan yang kuat pasti akan melaksanakan ibadah dengan tertib, memiliki akhlak yang mulia dan bermuamalat dengan baik.

Ibadah seseorang tidak akan diterima oleh Allah Swt kalau tidak dilandasi dengan keimanan yang benar. Karena masalah aqidah adalah masalah fundamental dalam Islam. Ia menjadi titik tolak pemulaan muslim. Sebaiknya tegaknya aktivitas keislaman dalam hidup dan kehidupan seseorang itulah yang dapat menerangkan bahwa orang itu memiliki aqidah atau menunjukkan kualitas keimanan yang dimiliki.

Manusia hidup atas kepercayaannya. Atau dengan kata lain, tinggi rendahnya nilai kehidupan manusia tergantung kepada kepercayaan yang dimilikinya. Sebab itulah kehidupan pertama dalam Islam dimulai dengan keimanan. ${ }^{35}$ Dalam tujuan pendidikan Islam yang diterangkan oleh Omar Muhammad al-Toumy terdapat tujuan yang bersifat khusus. Tujuan tersebut sesuai dengan tujuan pendidikan keimanan, diantaranya yaitu: (1) memperkenalkan pada generasi muda akan aqidah islam, dasar-dasarnya, asal-usul ibadah dan tata cara pelaksanaannya dengan baik dan benar. (2) menanamkan keimanan kepada Allah, malikat-malikat Allah, rasul-rasul Allah, kitab-kitab Allah, dan hari akhir berdasarkan pada paham kesadaran dan keharusan perasaan. (3) mendidik naluri, motivasi, dan keinginan generasi muda dan membentenginya dengan aqidah dan nilai-nilai dan membiasakan mereka menahan motivasi-motifasinya, mengatur emosi dan membimbingnya dengan baik. (4) menanamkan iman yang kuat kepada Allah pada diri mereka dan menguatkan perasaan agama dan dorongan agama dan akhlak pada diri mereka, dan menunmbuhkan hati mereka

${ }^{35}$ Nasrudi Razak, Dienul Islam, (Bandung: al-ma'arif, 1977), h. 120. 
dengan kecintaan, zikir, taqwa, dan takut kepada Allah. (5) membersihkan hati mereka dari dengki, hasad, irihati, benci dan sifat tercela lainnya. ${ }^{36}$

\section{Pendidikan Keimanan dan Urgensinya}

Pendidikan keimanan merupakan penanaman aqidah yang harus diberikan kepada anak sejak dini. Ibarat bangunan aqidah adalah pondasi atau dasar tempat berdirinya sebuah bangunan. Semakin tinggi bangunan yang didirikan maka pondasinya harus semakin kokoh. Kalau pondasinya lemah maka bangunan akan cepat ambruk. Tidak ada bangunan tanpa pondasi. ${ }^{37}$

Penanaman aqidah ini dimulai dengan mengenalkan kalimat tauhid. Kemudian menciptakan suasana religius dalam rumahtangga. Dengan dasar keimanan yang tertanam kuat di dalamjiwa akan akan melandasai pengetahuan anak selanjutnya dalam semua aspek kehidupan. Nashih Ulwan menjelaskan bahwa kewajiban pendidik yang utama adalah menumbuh kembangkan jiwa religius pada diri anak atas dasar aqidah yang kuat dan pemahaman Islam yang benar sehingga anak akan terkait dengan Islam baik dari aspek aqidah, ibadah maupun akhlak.

Setelah itu anak hanya akan mengenal Islam sebagai agamanya, al-Quran sebagai imamnya dan nabi Muhammad Saw sebagai pemimpin dan teladanny..$^{38}$ Pemahaman menyeluruh tentang pendidikan Islam sangat penting. Islam memandang potensi rohaniyah telah didasari oleh potensi fitrah islamiyah, sebagaimana firman Allah SWT dalam surat ar-Rum ayat 30: yang artinya "Maka hadapkanlah wajahmu dengan lurus kepada agama Allah; (tetaplah atas) fitrah Allah yang Telah menciptakan manusia menurut fitrah itu. tidak ada peubahan pada fitrah Allah. (Itulah) agama yang lurus; tetapi kebanyakan manusia tidak mengetahui fitrah Allah".

Fitrah Allah dalam ayat tersebut maksudnya ciptaan Allah. Manusia diciptakan Allah mempunyai naluri beragama yaitu agama tauhid. kalau

${ }^{36}$ Omar Muhammad al-Toumy al-Syahbani, Falsafah Pendidikan Islam, trans. Hasan Langulung (Jakarta: Bulan Bintang, 1979), h. 423-424.

${ }^{37}$ Yunahar, Kuliah Aqidah Islam, h. 9-10.

${ }^{38}$ Ulwan, Pedoman Pendidikan Anak Dalam Islam, Jilid II, h. 151. 
ada manusia tidak beragama tauhid, maka hal itu tidaklah wajar. mereka tidak beragama tauhid itu hanyalah lantaran pengaruh lingkungan. ${ }^{39}$ Dalam hadits Nabi Muhammad SAW menegaskan: Diriwayatkan dari Abi Hurairah bahwasanya ia berkata, Rasulullah Saw bersabda: setiap anak dilahirkan dalam fitrahnya (potensi untuk beriman kepada Allah dan kepada yang baik). Orang tuanyalah yang menjadikan anak itu menjadi Yahudi, Nasarani ataupun Majusi.

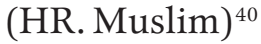

Di dalam Quran surat al-A'rafayat 172 juga telah ditegaskan oleh Allah SWT dalam firmanNya yang artinya; "Dan (ingatlah), ketika Tuhanmu mengeluarkan keturunan anak-anak Adam dari sulbi mereka dan Allah mengambil kesaksian terhadapjiwa mereka (seraya berfirman): "Bukankah Aku Ini Tuhanmu?" mereka menjawab: "Betul (Engkau Tuban kami), kami menjadi saksi". (Kami lakukan yang demikian itu) agar di hari kiamat kamu tidak mengatakan: "Sesungguhnya kami (Bani Adam) adalah orang-orang yang lengah terhadap Ini (keesaan Tuhan)".

Dari ayat tersebut teranglah bahwa setiap bayi yang terlahir ke dunia ini telah dibekali dengan aqidah islamiyah. Bahkan sebelum terlahir pun telah berjanji di hadapan Allah SWT bahwa dirinya siap mempertuhankan-Nya. Oleh sebab itu, agar janji itu tetap tertanan dan tidak lupa maka orang tua wajib mengikatnya dengan sungguh-sungguh. ${ }^{41}$ Tidaklah pantas apabila orang tua muslim membiarkan anak-anaknya terjerumus dan berkiblat kepada aqidah Yahudi, Nasarani ataupun Majusi. Dengan demikian dapat dipahami bahwa baik buruknya fitrah anak sangat tergantung pada pendidikan. Pendidikan pertama dan utama adalah di rumah tangga.

\footnotetext{
${ }^{39}$ Departemen Agama RI, Al-Qur'an Dan Tafsirnya, h. 137.

${ }^{40}$ Imam Abu Husain Muslim Hajjaj al-Qusyairi, Shahih Muslim, trans. Adib Bisri Musthofa, juz IV, n.d., h. 587.

${ }^{41}$ M. Nipan Abdul Halim, Anak Shaleh Dambaan Keluarga, cet. II (Yogyakarta: Mitra Pusaka, 2001), h. 49.
} 


\section{Kesimpulan}

Pendidikan keimanan (aqidah) merupakan pondasi/ landasan yang harus diberikan kepada peserta didik. Setiap anak yang dilahirkan memiliki potensi (fitrah) termasuk potensi rohaniyah yang perlu terus dikembangkan melalui pendidikan.

Pendidikan keimanan telah dicerminkan dan diatur di dalam al-Quran. Sehingga setiap muslim yang akan menanamkan pendidikan keimanan kepada anak-anaknya harus berpedoman dan berpatokan pada al-Quran, seperti halnya tentang materi pendidikan keimanan, metode, tujuan serta urgensi dari pendidikan keimanan bagi umat Islam.[]

\section{Daftar Pustaka}

Abdullah, Abdurrahman Shalih. Landasan Dan Tujuan Pendidikan Menurut Al-Qur'an Dan Implementasinya,. Bandung: Diponegoro, 1992.

Achmadi. Ideology Pendidikan Isalm,. Yogyakarta: Pustaka Pelajar, 2010.

Darmaningtyas. Pendidikan Yang Memiskinkan,. Yogyakarta: Galang Press, 2004.

Departemen Agama RI. Al-Qur'an Dan Tafsirnya,. Jilid VII. Yogyakarta: Dana Bhaktii Wakaf, 1995.

Halim, M. Nipan Abdul. Anak Shaleh Dambaan Keluarga,. Cet. II. Yogyakarta: Mitra Pusaka, 2001.

Hitami, Munzir. Mengonsep Kembali Pendidikan Islam,. Riau: Infinite Press, 2004.

Ikk, Syaikh Khalid Abdurrahman al-. Pedoman Pendidikan Anak Menurut AlQur'an Dan Sunnah,. Solo: al-Qowam, 2009.

Mujib, Abdul, and Yusuf Mudzakir. Ilmu-Ilmu Pendidikan Islam,. Jakarta: Kencana Prenada Media, 2006.

Muslim, Al-Imam. Shahih Muslim,. Translated by Makmur Daud. Jilid 1. Malaysia: Klang Book Centre, 1995. 
Nata, Abudin. Filsafat Pendidikan Islam I,. Jakarta: Logos Wacana Ilmu, 1997. Penulis, Tim. “Kamus Besar Bahasa Indonesia,.” Jakarta: Balai Pustaka, 2002. Purwanto, Ngalim. Ilmu Pendidikan, Teoritis Dan Praktis,. Bandung: Remaja Rosda Karya, 1995.

Qusyairi, Imam Abu Husain Muslim Hajjaj al-. Shahih Muslim,. Translated by Adib Bisri Musthofa. juz IV, n.d.

Qutb, Muhammad. Sistem Pendidikan Islam,. Translated by Salman Harun. Bandung: al-Maarif, 1993.

Rakhmat, Jaluddin. Islam Alternatif Ceramah-Ceramah Di Kampus,. Bandung: Mizan, 2003.

Razak, Nasrudi. Dienul Islam,. Bandung: al-ma’arif, 1977.

Rusn, Abidin Ibn. Pemikiran Al-Ghozali Tentang Pendidikan,. Yogyakarta: Pustaka Pelajar, 1998.

Sabiq, Sayid. Aqidah Islam,. Bandung: Diponegoro, 1993.

Shihab, M. Quraish. Wawasan Al-Qur'an,. Bandung: PT. Mizan Pustaka, 2004. Smith, Hustan, and Cyril Glasse. Ensiklopedi Islam (Ringkas),. Translated by Ghufran, A. Mas'adi. 1st ed. Vol. cet. 2. Jakarta: Raja Grafindo Persada, 1999.

Suhartono, Suparlan. Filsafat Pendidikan, Yogyakarta: ar-Ruzz Media, 2009.

Syahbani, Omar Muhammad al-Toumy al-. Falsafah Pendidikan Islam,. Translated by Hasan Langulung. Jakarta: Bulan Bintang, 1979.

Tafsir, Ahmad. "Pendidikan Keimanan Sebagai Core Sistem Pendidikan (Upaya Strategis Menyelamatkan Bangsa,." In Ta'dib Jurnal Pendidikan Islam, No. 2. Vol. Vol. 1, 2001.

Tim Broad Based Education Depdiknas. Kecakapan Hidup Melalui Pendekatan Pendidikan Berbasis Luas,. Surabaya: SIC, 2002.

Ulwan, Nashih. Pedoman Pendidikan Anak Dalam Islam, Jilid I, n.d.

- - - . Pedoman Pendidikan Anak Dalam Islam, Jilid II, n.d. 
Undang-undang Republik Indonesia. Tentang Sisitem Pendidikan Nasional, Pub. L. No. 2, Pasal 3 Bab II (2003).

Yunahar, Ilyas. Kuliah Aqidah Islam,. Yogyakarta: Lembaga Pengkajian dan Pengamalan Islam-LIPPI, 1992.

Zaini, Hasan. TafsirTematik Ayat-Ayat Kalam,. Jakarta: Radar Jaya Offset, 1997.

Zuhdi, Masfuk. Studi Islam,. Jilid I. Jakarta: Rajawali, 1988. 